\title{
Correlates of illness behaviour related to orofacial infections of odontogenic origin among adults in a semi urban community in Nigeria
}

\author{
Adegbayi A. Adekunle ${ }^{1}$, Omolara G. Uti ${ }^{2}$ and Oyinkansola O Sofola ${ }^{2}$ \\ Ghana Med J 2019; 53(4): 294-298 doi: http://dx.doi.org/10.4314/gmj.v53i4.7
}

\author{
${ }^{1}$ Department of Oral and Maxillofacial Surgery, Lagos University Teaching Hospital, Idi-Araba, Lagos, Nige- \\ ria \\ ${ }^{2}$ Department of Preventive Dentistry, College of Medicine, University of Lagos/Lagos University Teaching Hos- \\ pital, Idi-Araba, Lagos, Nigeria
}

Corresponding author: Adekunle AA

E-mail: aadeadekunle01@gmail.com

Conflict of interest: None declared

\begin{abstract}
SUMMARY
Background: Infections of facial spaces in the maxillofacial region occur in most cases as a complication of odontogenic infections. It often results in substantial morbidity, with serious and potentially life threatening outcomes if allowed to progress without prompt medical attention.

Objective: To identify factors that determine illness behaviour related to maxillofacial space infections.

Method: This was a descriptive cross-sectional study of adult residents of pakoto community, Ifo local government area, Ogun state. The study was conducted using an interviewer administered questionnaire which included key information about respondents' awareness of predisposing factors of maxillofacial space infections; common actions taken with regards to treatment, and the factors that influenced their utilization of the available oral health care service.

Results: A total of 187 individuals were sampled, mean age was 30.5(SD 11.7) years with majority being females (59.4\%) The proportion of the total respondents who reported a history suggestive of orofacial space infection was $20.3 \%(n=38)$. Visiting a patent medicine dealer $(26.3 \%)$ along with visiting a dentist $(31.6 \%)$ were the illness behaviours most frequently engaged in by respondents who have had an orofacial swelling following a toothache, with majority (73.7\%) indicating the action they took was based on what was most convenient.

Conclusion: This study has revealed that engagement in unorthodox practises by individuals in a semi-urban community studied is prevalent, and influenced by factors such as age, gender, level of education and occupation.
\end{abstract}

Keywords: Odontogenic infection, semi-urban community, illness behaviour Funding: None

\section{INTRODUCTION}

Infections of the facial spaces in the maxillofacial region occur in most cases as a complication of odontogenic infections, presenting as an acute complication of a previously untreated chronic disease. ${ }^{1,2}$ Facial space infections often result in substantial morbidity, with serious and potentially life threatening outcomes ${ }^{3,4}$ like septicaemia, mediastinitis, empyema thoracic, necrotising fasciitis, laryngeal spasm, renal failure and death, ${ }^{5}$ if allowed to progress without prompt intervention.

The treatment of facial space infections includes aggressive intravenous high dose antibiotics (usually penicillin or cephalosporins and metronidazole), analgesic and fluid therapy in addition to establishment of surgical drainage and elimination of the source of infection., ${ }^{2,4,6}$
Predisposition to developing facial space infection may be attributed to factors which include poor health seeking behavior, poor oral hygiene, suboptimal nutritional status, abuse of antibiotics among others. ${ }^{2,7-10}$

Illness behavior refers to the way in which symptoms are perceived, evaluated, and acted upon by a person who recognizes some pain, discomfort or other signs of organic malfunction. ${ }^{11,12}$ Illness behaviours include dismissal of symptoms, self-help strategies (such as visiting a chemist, antibiotic abuse, use of herbal concoction etc), and also visiting an approved healthcare facility. It has been demonstrated from various studies that an individual's decision to engage in a particular illness behaviour is influenced by a variety of socio-economic variables, sex, age, social status, type of illness, access to services and perceived quality of the service. 
This study seeks to identify the factors that determine illness behaviour related to maxillofacial space infections in a semi-urban community, as there is paucity of studies in the literature focused on this population group.

\section{METHODS}

This was a descriptive cross-sectional study carried out in Pakoto community, Ifo local government area, Ogun state. Due to its proximity to the megacity of Lagos, a large proportion of the population of this community transit to Lagos daily for work. Participants were adults of 18years and above systematically selected from alternate streets using a sampling frame consisting of all the streets in the community. A household/door-to-door survey of adult members on selected streets was then done. Individuals less than 18years of age and individuals who did not consent to be part of the study were excluded.

Ethical approval was obtained from the Lagos University Teaching Hospital Health Research Committee (ADM/DCST/HREC/APP/118) before commencement of data collection. Willing participants who met the inclusion criteria and from whom informed consent was obtained prior to data collection were included.

An Interviewer administered questionnaire was administered to the participants. It included key information about: respondents' bio data, awareness of predisposing factors of maxillofacial space infections, common actions taken with regards to treatment by affected individuals, the factors that influenced these actions and their utilization of dental health care.

Data collected was analyzed using Statistical Package for Social Sciences software for windows (IBM SPSS Statistics for Windows, Version 20.0. Armonk, NY: IBM Corp). Test of association was done using chi square test and the statistical significance of outcomes was evaluated at $95 \%$ confidence level and $p \leq 0.05$.

\section{RESULTS}

A total of 187 individuals consented to participate in this study out of 211 individuals approached, resulting in a response rate of $88.6 \%$. The age range of participants was $18-70$ years (mean $30.5, \mathrm{SD} \pm 11.7$ years). Females made up $59.4 \%$ of the study participants and $34.8 \%$ were students (Table 1).

Majority of the respondents (77.5\%) believed that spread of infection from an oral focus can result in soft tissue swellings around the oral and peri-oral region (Table 2), and $73.3 \%$ rated an oral/peri-oral soft tissue swelling with pus discharge an indication of a serious condition requiring prompt medical intervention (Figure 1).
Table 1 Socio - demographic data of respondents

\begin{tabular}{|c|c|}
\hline Item & $\mathbf{N}(\%)$ \\
\hline \multicolumn{2}{|l|}{ Age } \\
\hline $18-25$ & $79(42.2)$ \\
\hline $26-45$ & $80(42.8)$ \\
\hline $46-65$ & $26(13.9)$ \\
\hline$>65$ & $2(1.1)$ \\
\hline Total & $187(100.0)$ \\
\hline \multicolumn{2}{|l|}{ Sex } \\
\hline Male & $76(40.6)$ \\
\hline Female & $111(59.4)$ \\
\hline Total & $187(100.0)$ \\
\hline \multicolumn{2}{|l|}{ Ethnicity } \\
\hline Yoruba & $128(68.4)$ \\
\hline Igbo & $46(24.6)$ \\
\hline Hausa & $8(4.3)$ \\
\hline Others & $5(2.7)$ \\
\hline Total & $187(100.0)$ \\
\hline \multicolumn{2}{|l|}{ Educational level } \\
\hline no formal education & $33(17.6)$ \\
\hline Primary & $30(16.0)$ \\
\hline secondary & 93 (49.7) \\
\hline Tertiary & $31(16.6)$ \\
\hline Total & $187(100.0)$ \\
\hline \multicolumn{2}{|l|}{ Occupation } \\
\hline Student & $65(34.8)$ \\
\hline professionals & $32(17.1)$ \\
\hline semi professionals & $3(1.6)$ \\
\hline skilled workers & $40(21.4)$ \\
\hline Unemployed & $12(6.4)$ \\
\hline Retired & $2(1.1)$ \\
\hline Trader & $33(17.6)$ \\
\hline Total & $187(100.0)$ \\
\hline \multicolumn{2}{|l|}{ marital status } \\
\hline Single & $88(47.1)$ \\
\hline Married & $95(50.8)$ \\
\hline Widowed & $4(2.1)$ \\
\hline Total & $187(100.0)$ \\
\hline
\end{tabular}

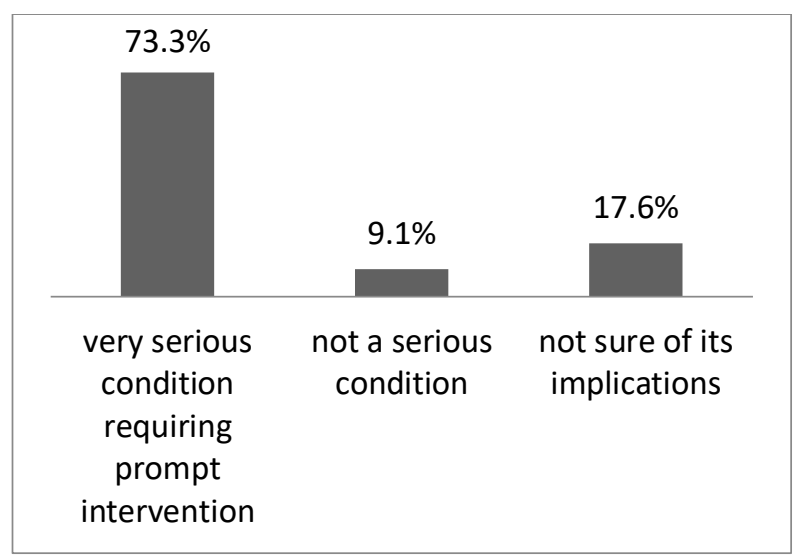

Figure 1 Respondents rating of seriousness of orofacial infection of odontogenic origin 
Table 2 Respondents beliefs about the etiology of orofacial infection of odontogenic origin

\begin{tabular}{|l|l|}
\hline Item & N (\%) \\
\hline Family inheritance & $20(10.7)$ \\
\hline Spiritual attack/curse & $7(3.7)$ \\
\hline Punishment for disobedience & $5(2.7)$ \\
\hline $\begin{array}{l}\text { Spread of infection into the tissues from the } \\
\text { tooth }\end{array}$ & $145(77.5)$ \\
\hline Others & $10(5.3)$ \\
\hline Total & $187(100.0)$ \\
\hline
\end{tabular}

The proportion of the total respondents who reported a history suggestive of orofacial space infection was $20.3 \%$ $(n=38)$. From this pool, only $31.6 \%(n=12)$ reported utilizing the service of a dentist on account of the reported condition (Table 3), while others engaged in behaviors such as visiting a patent medicine dealer, using herbal concoctions etc.

Table 3 also shows that majority of those who engaged in various illness behaviours were females, except the category of those who self-medicated, where males had the majority.

Table 3 Reported illness behaviours of respondents who had a swelling

\begin{tabular}{|l|l|l|l|}
\hline Illness behaviour & $\begin{array}{l}\text { Frequency } \\
\text { (\%) }\end{array}$ & \multicolumn{2}{|c|}{$\begin{array}{l}\text { Sex distribution } \\
\text { N(\%) }\end{array}$} \\
\hline & & male & female \\
\hline Self -medication & $9(23.7)$ & $5(55.6)$ & $4\{44.4)$ \\
\hline Visited a chemist & $10(26.3)$ & $4(40)$ & $6(60)$ \\
\hline $\begin{array}{l}\text { Attempted to remove the } \\
\text { tooth myself }\end{array}$ & $1(2.6)$ & 0 & $1(100)$ \\
\hline Applied herbal concoction & $6(15.8)$ & $1(16.7)$ & $5(83.3)$ \\
\hline Visited a dentist & $12(31.6)$ & $4(33.3)$ & $8(66.7)$ \\
\hline Total & $38(100)$ & $14(36.8)$ & $24(63.2)$ \\
\hline
\end{tabular}

Majority of those who reported self-medication were older than 45 years of age $(55.6 \%, n=5)$, while majority of those who engaged in other reported illness behaviours were within the 18-34 years age group.

A significant majority of these respondents $(73.7 \%$, $\mathrm{n}=28$ ) who reported an episode of orofacial space infection indicated the treatment option they choose was largely influenced by convenience (Table 5).
Table 4 Relationship between illness behaviour and age of respondents

\begin{tabular}{|l|l|l|l|l|}
\hline \multicolumn{1}{|c|}{ Item } & \multicolumn{3}{c|}{ Age } & \multirow{2}{*}{ Total } \\
\cline { 1 - 4 } & $\begin{array}{l}18- \\
34\end{array}$ & $\begin{array}{l}35- \\
44\end{array}$ & $>45$ & \\
\hline Self-Medication & 2 & 2 & 5 & 9 \\
\hline Visited a chemist & 5 & 3 & 2 & 10 \\
\hline $\begin{array}{l}\text { Attempted to remove the tooth } \\
\text { myself }\end{array}$ & 1 & 0 & 0 & 1 \\
\hline Applied herbal concoction & 4 & 0 & 2 & 6 \\
\hline Visited a dentist & 8 & 1 & 3 & 12 \\
\hline Total & $\mathbf{2 0}$ & 6 & 12 & 38 \\
\hline
\end{tabular}

Table 5 Determinants of illness behaviour in respondents with self-reported orofacial infection experience

\begin{tabular}{|c|c|}
\hline Item & Frequency $(\%)$ \\
\hline $\begin{array}{l}\text { Advice from family and } \\
\text { friends }\end{array}$ & $1(2.6)$ \\
\hline Lack of money & $7(18.4)$ \\
\hline The convenient option & $28(73.7)$ \\
\hline Followed cultural beliefs & $2(5.3)$ \\
\hline Total & $38(100)$ \\
\hline
\end{tabular}

Table 6 Respondents opinion on usual actions taken by members of the community who experience orofacial space infection

\begin{tabular}{|l|l|}
\hline \multicolumn{1}{|c|}{ Actions } & $\mathbf{N}(\mathbf{\%})$ \\
\hline Apply herbal concoction & $4(10.5)$ \\
\hline Apply heat massage & $1(2.6)$ \\
\hline Visit a chemist & $6(15.8)$ \\
\hline Visit a dentist & $27(71.1)$ \\
\hline Total & $38(100.0)$ \\
\hline
\end{tabular}

Overall, A higher proportion of those individuals who engaged in unhealthy illness behaviors (did not utilize the service of a dentist) were within the 18-34 years age group $(31.6 \%, n=12)$ females $(42.1 \%, n=16)$, had secondary school level education $(36.8 \%, \mathrm{n}=14)$, married $(52.6 \%, \mathrm{n}=20)$ and skilled workers $(26.3 \%, \mathrm{n}=10)$. The relationship between illness behaviour and occupation was significant $(\mathrm{p}=0.038)$ (Tables 7 and 8$)$. No other significant association was found between the variables.

Table 7 Showing Relationship between illness behaviour and level of education

\begin{tabular}{|c|c|c|c|c|c|}
\hline \multirow[t]{2}{*}{ Illness Behaviour } & \multicolumn{4}{|c|}{ Educational Level } & \multirow{2}{*}{$\begin{array}{l}\text { Total } \\
\text { (\%) }\end{array}$} \\
\hline & None $(\%)$ & Primary (\%) & Secondary $(\%)$ & Tertiary (\%) & \\
\hline Self- medication & 0 & $4(10.5)$ & $5(13.2)$ & 0 & $9(23.6)$ \\
\hline Visited a chemist & $1(2.6)$ & $1(2.6)$ & $7(18.4)$ & $1(2.6)$ & $10(26.3)$ \\
\hline Attempted to remove the tooth myself & 0 & 0 & $1(2.6)$ & 0 & $1(2.6)$ \\
\hline Applied herbal concoction & $2(5.2)$ & $1(2.6)$ & $1(2.6)$ & $2(5.2)$ & $6(15.9)$ \\
\hline Visited a dentist & $2(5.2)$ & $4(10.5)$ & $6(15.9)$ & 0 & $12(31.6)$ \\
\hline Total & $5(13.2)$ & $10(26.3)$ & $20(52.6)$ & $3(7.9)$ & $38(100)$ \\
\hline
\end{tabular}




\section{Original Article}

Table 8 Showing relationship between illness behaviour and occupation

\begin{tabular}{|l|l|l|l|l|l|l|}
\hline \multicolumn{1}{|c|}{ Illness behaviour } & \multicolumn{5}{|c|}{ Occupation } & \multicolumn{2}{|c|}{ Total (\%) } \\
\cline { 2 - 7 } & $\begin{array}{l}\text { Student } \\
(\mathbf{\%})\end{array}$ & $\begin{array}{l}\text { Skilled } \\
\mathbf{( \% )}\end{array}$ & labourer & $\begin{array}{l}\text { Civil Servant } \\
(\mathbf{\%})\end{array}$ & Trader (\%) & Others (\%) \\
\hline Visited a dentist & $4(10.5)$ & $2(5.3)$ & $2(5.3)$ & $4(10.5)$ & $0(0.0)$ \\
\hline Other illness behaviours & $1(2.6)$ & $10(26.3)$ & $2(5.3)$ & $7(18.4)$ & $6(15.8)$ & $26(68.4)$ \\
\hline Total & $5(13.2)$ & $12(31.6)$ & $4(10.5)$ & $11(28.9)$ & $6(15.8)$ & $38(100.0)$ \\
\hline
\end{tabular}

$\chi 2=10.175 \quad \mathrm{p}=0.038$

\section{DISCUSSION}

Orofacial infections commonly arise as a complication of an untreated odontogenic infection either of the tooth or periodontium, the condition can often be fatal, if left untreated or not properly treated. In the developed world, fatal dental infections are rare in patients with intact immune response. However, in the semi-urban setting where this study was conducted, factors such as literacy, occupation and earning power, poor nutrition and poor attitude towards general health and wellbeing are factors which impact generally on individual immunity and health behaviours hence may predispose strongly to progression of odontogenic infection. ${ }^{4-6,13}$

Identification of illness behaviours in a population can help in planning appropriate interventions, for example, if it is a norm for individuals who experience an episode of orofacial infection to seek help from a local chemist shop, it may then be possible to train the local chemist to refer such individuals to the nearest health facility. ${ }^{14}$

The view is often that desired health care seeking behaviour is for an individual to respond to an illness episode by seeking first and foremost help from a trained medical practitioner, in a formally recognized health care setting. ${ }^{15}$ Results from this study revealed that though majority of the rural dwellers sampled considered orofacial space infection as a serious condition, still majority of those who had experienced an episode engaged in unwholesome practises such as self-medication, use of herbal concoction, visit to patent medicine dealers, and even attempt at extraction of own tooth. This may be due to the perceived convenience and low cost of such "interventions".

In addition, majority of respondents in this study considered orofacial infection as a serious condition requiring immediate medical attention, which on the surface would suggest that the perceived severity of this condition would be the sole determinants of an individual's response. Yet many people failed to see a dentist or practised self-care despite the presence of serious symptoms. These may suggest that illness behaviours is influenced by social and cultural factors in addition to (and sometimes instead of) physiological condition. ${ }^{11}$
This is further compounded by the absence of a universal health insurance scheme in developing countries like Nigeria, which deters patients from seeking regular dental care, and this may even encourage patients with acute dental infection to engage in unwholesome illness behaviours and unorthodox practices which have the potential of causing serious complications locally and systemically. ${ }^{1,2}$ Although there is National Health Insurance Scheme (NHIS) in Nigeria, the population coverage is low, ${ }^{16}$ and it does not cover treatment of orofacial infections beyond simple extractions.

Although the female gender has been associated with positive health seeking behavior, ${ }^{17}$ and results from this study also showed that self-reported utilization of oral health care service was higher among the female gender in the study population. This is in agreement with the finding of Adegoke ${ }^{17}$ that females had a favourable disposition towards the practises of health enhancing behaviors than males. However results of this study also revealed that a higher percentage of those who reportedly engaged in unorthodox illness behaviours were females, this may be explained with the view of Orubuloye ${ }^{18}$, who stated that rural women may respond differently from urban women on matters relating to their health treatment and that of their children. ${ }^{15}$ This result may as well just be attributable to the fact that more females were sampled than males during the study period.

Previous studies ${ }^{17}$ have documented the significant influence of education on health behaviour. Although results of this study did not reveal a direct significant association between education and illness behaviour of the respondents, it rather showed a significant association between occupation and illness behaviour of the respondents. It is common knowledge that education is related to occupation, and results from this study showed that majority of respondents who engaged in negative illness behaviours were skilled labourers and traders with intermediate and low level of formal education, while majority of those who had utilized the services of a dentist were professionals with higher level of formal education. This finding agrees with Uitenbroek ${ }^{19}$ study which found that better educated and employed individuals behave in a more healthy way compared with less well educated and unemployed individuals. 
This study has revealed a generally poor oral health seeking behaviour among the population studied, with less than a quarter of respondents having ever utilized the service of a dentist. Majority of respondents had no reason for having not utilized the services of a dentist, while cost of service was the second highest reason given for not visiting the dentist, confirming lack of perceived need and cost of service as previously indicated in past studies as the two top influencing health care utilization among Nigerians. ${ }^{7,8,10,15}$

Limitations of this study included the small sample size, and perhaps organization of a focus group discussion prior to implementation of data collection could have helped in formulation of a more accurate data collection tool.

\section{CONCLUSION}

This study has revealed that engagement in unorthodox practises by individuals in a rural community studied is influenced by factors such as age, gender, level of education and occupation. Further extensive study is needed to get a more accurate picture, with results that can be generalised to the whole population; this will have wide reaching implications on national health planning and promotion as majority of Nigeria's population are distributed in rural and semi-urban areas.

\section{REFERENCES}

1. Gbolahan OO, Olowookere S, Aboderin A, Omopariola O. Ludwig's Angina following self application of an acidic chemical. Ann Ibadan Postgrad Med. 2012;10(1):34-7.

2. Amponsah E, Donkor P. Life-threatening Oro-facial infections. Ghana Med J. 2007;41(1):33-6.

3. Yonetsu K, Izumi M, Nakamura T. Deep facial infections of odontogenic origin: CT assessment of pathways of space involvement. Am J Neuroradiol. 1998;19(1):123-8.

4. Gupta M, Singh V. A retrospective study of 256 patients with space infection. J Maxillofac Oral Surg. 2010;9(1):35-7.

5. Ugboko V, Ndukwe K, Oginni F. Ludwig's Angina : An Analysis of Sixteen Cases in a Suburban Nigerian Tertiary Facility . African $J$ oral Heal. 2005;2(1\&2):16-23.

6. Osunde OD, Akhiwu BI, Efunkoya AA, Adebola AR, Iyogun CA, Arotiba JT. Management of fascial space infections in a Nigerian teaching hospital: A 4year review. Niger Med J. 2012;53(1):12-5.

7. Bamise C, Bada T, Bamise F, Ogunbodede E. Dental Care Utilization and Satisfaction of Residential University Students. Libyan J Med. 2008;80601:1-6.

8. Akaji E, Oredugba F, Jeboda S. Utilization of dental services among secondary school students in Lagos, Nigeria. Niger Dent J. 2008;15(2):87-91.

9. Braimoh O, Ofili A. Utilisation of Dental Services Among Patients in a Tertiary Health Institution in Nigeria. $J$ Oral Heal Community Dent. 2013;7(2):91-4.

10. Ajayi E, Ajayi Y. Utilization of dental services in a population of Nigerian University students. Niger Dent J. 2008;15(2):83-6.

11. Illness Behavior and the Sick Role [Internet]. Available from: http://davidscottsociology.tripod.com/sitebuildercontent/sitebuilderfiles/illnessbehaviorandthesickrole.pdf

12. Mechanic D. Illness Behaviour: An Overview. In: Illness Behavior. Boston, MA: Springer US; 1986. p. 101-9.

13. Opeodu OI, Arowojolu MO, Gbadebo SO, Ibiyemi TS. An Audit of Pattern of Patients' Presentation at the Periodontics Clinic of the University College Hospital, Ibadan. Ann Ibadan Postgrad Med. 2009;7(1):16-20.

14. A rapid assessment of health seeking behaviour in relation to sexually transmitted disease. SEF/PRS/STD -GPA/WHO. 1995.

15. Omotoso D. Health Seeking Behaviour among the Rural Dwellers in Ekiti State, Nigeria. African Res Rev. 2010;4(2):125-39.

16. Okpani AI, Abimbola S. Operationalizing universal health coverage in Nigeria through social health insurance. Niger Med J. 2015;56 (5):305-10.

17. Adegoke AA. Correlates of Health Behavior Practices Among Literate Adults of South West, Nigeria. African Symp. 2010;10(2):26-38.

18. Orubuloye I. Disease, Illness and Society. Centre for Population and Health Resources, Ado-Ekiti , Nigeria. National Open University of Nigeria (NOUN); 2003.

19. Uitenbroek DG, Kerekouska A, Festchieva N. Health Lifestyle behavior and sociodemographics characteristics; a study of verna, glasgow and edinburgh. Soc Sci Med. 1996;43(3):367-77. 